$\begin{array}{r}\text { Interdisciplinary Contexts of Special Pedagogy } \\ \text { NUMBER 31/2020 } \\ \text { ALICJA MIRONIUK } \\ \text { University of Wroclaw, Poland } \\ \hline\end{array}$

\title{
(Un)seen difference, i.e. regarding the image of persons with physical disabilities in selected feature films
}

\begin{abstract}
Alicja Mironiuk, (Un)seen difference, i.e. regarding the image of persons with physical disabilities in selected feature films. Interdisciplinary Contexts of Special Pedagogy, no. 31, Poznań 2020. Pp. 173-199. Adam Mickiewicz University Press. ISSN 2300-391X. e-ISSN 2658-283X. DOI: https:// doi.org/10.14746/ikps.2020.31.08
\end{abstract}

The paper presents the results of a qualitative research on a topic of the film imagery of people with physical disabilities. Selected feature films were analysed on the basis of specific questions regarding femininity, masculinity and sexuality of persons with physical disabilities. Additionally, the research was also based on three imagery stages: the early-exploitation, the super-cripple and normality. The main result of the analysis is to settle two discourses: the main and the alternative. Despite the social changes, most popular representations are stereotypical, presenting disability as a total category and are shown from the masculine perspective. The most important presentation within the alternative discourse must include disability as a transparent, unseen difference.

KEY WORDS: physical disability, feature films, media imagery of persons with physical disabilities

\section{Introduction}

Currently, we live in a visual culture, and how we look decides on our image both in the real, and the virtual world. Can an unseen category exist within the image culture? How may one understand 
the aforementioned unseen? Is it a result from the absence of a particular category? Or quite the contrary, from its universality, obviousness? The above questions were inspiration for undertaking qualitative studies, regarding the critical analysis of visual culture sources (films) within the context of persons with disabilities portrayed there. The object of the study was to present the image of persons with physical disabilities within selected feature films, and the change of this image. The following article is an attempt to summarise the conclusions from the aforementioned studies. Subheadings organise the empirical sources based on posed detailed questions.

\section{Image of women with physical disabilities}

The first study plane was the film image of women with physical disabilities. The popular culture representations of female of bodies are always more disciplined from male portrayals, finding its cause in gender stereotypes, as well as, "screen rules". Female body is a cultural plane of inscribing meanings and "discipline" of conditioning activities. ${ }^{1}$ Physical appeal implicates health, sexual competencies and fertility. In the light of these considerations, women with disabilities present themselves as dis-abled non-women. This is a double discrimination - due to their disability and gender - it combines objectification with "dismemberment". A woman with disability is perceived through the wheelchair perspective, which becomes almost an additional organ, an integral part of her identity (therefore, reducing her to the man-machine category). Moreover, organism and its functions are subject to "dismemberment", with the central category being the problematic "body element" 2 related to disability. As previously mentioned, their femininity is negated - not only within the context of physical appeal, but also sexuality. By being different, women with disabilities are "presented as sexually promiscuous,

${ }^{1}$ Z. Melosik, Tożsamość, ciało i władza w kulturze instant, Oficyna Wydawnicza „Impuls”, Kraków 2010, p. 26.

2 Ibidem. 
asexual or innocent; they do not have the potential to express their sexuality in everyday life through clothing, hairstyle or intimate life". ${ }^{3}$ Fear related to the feeling of inadequacy (to the stereotypical image of femininity) and unattractiveness for the potential partner, as well as, social prejudices result in many women with physical disability resigning from accomplishing the role of a wife and mother. 4

The aforementioned social roles of women are referred to via the person of Terry, the heroine of An affair to remember. ${ }^{5}$ Her plans to become a wife, a mother and a socialite were impeded by a car accident, in result of which she had been paralysed from the waist down. The image of Terry as a woman with a physical disability is filled with inconsistencies. On the one side, the character experiences emancipation - for the first time she is working and earning money. Her activity may be perceived as overcoming the role of an "American housewife" of the 1950s, however Terry does not take up work "despite" her disability, but as a result of it. The tasks of an "ordinary" woman do not apply to her, and entering the path of regular employment in terms of her class provenance is the domain of men. Both disability and professional activity "abolish" her femininity. The trauma also results in her asexuality, and what is particularly interesting, it is action per se - the heroine automatically discards family happiness, and sexual satisfaction, not wanting her partner to see her as a person with a disability. Paradoxically, the image of the heroine is perfect - in each shot she is well dressed, her hair is well done, and she has impeccable make-up. However, her appeal is not "distorted" by the wheelchair, making the character static and passive, but beautiful. Usually, Terry is sitting as if she was going to get up, with her legs veiled with a blanket - she is an elegant showpiece "mounted" in a given room. Her disability is not obvious, and the film does not include references to the phases of

${ }^{3}$ C. Barnes, Niepetnosprawność, trans. P. Morawski, Wydawnictwo Sic!, Warszawa 2008, p. 114.

${ }^{4}$ L. Marszałek, Niepetnosprawność - kobiecość - rodzina, Wydawnictwo Uniwersytetu Kardynała Stefana Wyszyńskiego, Warszawa 2006, p. 160.

${ }^{5}$ An Affair to Remember, 1957, dir. L. McCarey, USA. 
the adaptation process regarding the acquired disability, as well as, related emotional or somatic difficulties. This results from the fact, that the heroine is treating her state as temporary, gathering funds for an undefined operation, that will "cure" her of disability. All the properties above, cause Terry to present herself as a person with a physical disability, and not a flesh-and-blood person, but a (melo)dramatic figure within the film plot.

An entirely different image of femininity is presented in the picture titled You're not You. ${ }^{6}$ The main protagonist, Kate, is suffering from amyotrophic lateral sclerosis, and she is in the terminal state. Despite the disability, the woman maintains conditioning rituals, and takes care of her appeal - however, at the basis of her activity is not solely for the purpose of caring for aesthetics, but primarily, maintaining the areas of independence. An important theme within the film is the need for sexual rehabilitation of persons with (progressing) physical disability, particularly adjusting the limited physical capabilities to sexual needs. ${ }^{7}$ Kate's husband denies her intercourse, explaining it with her bad health condition, causing her frustration and depression. The man becomes the guardian, nurse and a dietician, while discarding the role of a sexual partner. The decision for the omission of intercourse is made without her, based on stereotypes and not subjective needs. The heroine, during the terminal phase of the disease, decides on discarding her lifestyle, the expectation of her family, as well as, her unfaithful husband. Emancipation of the heroine, paradoxically, comes into existence in relation to her progressing disability. On the one hand, Kate ceases to be herself, with her previous life being discarded. On the second hand, as a person balancing on the thin line between life and death, with disability, she transgresses the boundaries of social expectations. The heroine's behaviour is an example of compensation - the weaker her body, the stronger her psyche. Contrary to Terry, Kate is

6 You're not you, 2004, dir. George C. Wolfe, USA.

${ }^{7}$ A. Ostrowska, Seksualność osób niepetnosprawnych, [in:] O seksualności osób niepetnosprawnych, (ed.) A. Ostrowska Instytut Rozwoju Służb Społecznych, Warszawa 2007, pp. 18-19. 
a multidimensional character. Her experience presents the complexity of the process of adaptation towards the acquired, progressing disability. Moreover, despite physical limitations, the protagonist does not agree to be decided upon regarding her sexuality.

An interesting theme within the film discourse of femininity within physical disability is introduced by the character of Dadina from La grande bellezza. 8 The protagonist, as the chief editor of a prestigious magazine, is a mature woman in a stable relationship. Dadina, as a person of low posture, is referring to the category of otherness perversely, while her character is filled with inconsistencies. She places her mature age against the particular perspective of low posture individuals ${ }^{9}$, saying that she has been looking at the world through a little girl's eyes for 60 years. The categories of maturity and infantility (not childishness) are constantly intertwined in her life. She has no children, but she cares for her friends as if they were children (as she refers to them), a part of her office filled with antiques, is a huge teddy bear. Dadina uses her status "in between" adulthood and intantility, between female and male roles, between health and disease - in order to become the Queen of Maladjusted, as she refers to herself. Her otherness allows her to question, or even transgress the established social framework.

\section{Image of men with physical disabilities}

While the analysis of study results were initiated with the description of characteristic portrayals of women with physical disabilities, the aforementioned perspective is dominated by images of men. The phenomenon has several reasons. The first is related to the roles that define masculinity traditionally: Impregnator - Protector Provider. ${ }^{10}$ In the case of men, caring for the well-being of the family

${ }^{8}$ La grande bellezza, 2013, dir. P. Sorrentino, Italy/France.

${ }^{9}$ Often mistaken for children due to their low posture.

${ }_{10}$ M. Dąsal, Męskie inicjacje - rytuaty w życiu współczesnego mężczyzny, [in:] Męskość w kulturze współczesnej, (eds.) A. Radomski, B. Truchlińska, Wydawnictwo Uniwersytetu Marii Curie-Skłodowskiej, Lublin 2008, p. 97. 
(Provider), and its security (Protector), particularly in the historical view, caused the risk of trauma. Within the context, trauma is evidence to masculinity and sacrifice, and disability (acquired) is less shocking than in terms of females. The film images of men with physical disability are dominated by the veteran narrative, and mostly set within the context of World War II and the Vietnam war.

One of the narrative axes of films that present men with physical disability is the process of adaptation for acquired disability. The loss of ability is demolishing the realisation of the aforementioned roles, and the man affected by it is no longer the:

- Impregnator - his sexual capability is lowered, as well as, his physical appeal. While fertility (e.g. in the case of damaging the spinal cord) remains, sexual intercourse requires adjusting to limitations;

- Protector - despite the fact that, in the case of a narrative of a crippled veteran, the realisation of the Protector role is the cause of the disability experience, it impedes its continuation. A disabled man is weak, and the integrity as well as, related vitality and bodily strength are lowered or removed;

- Provider - as the occurrence of a disability requires to readjust lifestyle, and long-lasting and systematic rehabilitation, the realisation of the Provider role is made difficult due to the necessity of adjusting professional activity to limitations (or the change of profession), increased weariness (related to the weakening of the nervous system) and costs of treatment and rehabilitation. A man with disability becomes the Patient.

Films that present veterans with disabilities often include a political context - they are a form of "familiarising" a given society with physical oddity (The Best Years of Our Lives) and help understand the challenges related to re-adapting to the post-war reality (The Men). Difficult experiences of men with acquired physical disability, help realise the personal (and in the broader perspective) social cost of political decisions, and in consequence, constitute a form of criticism against military operations - in terms of American cinematography, particularly the Vietnam war (Born on the Fourth of July, Coming Home). 
The plane for the adapting process to the acquired disability, is the wheelchair or a rehabilitation centre, which encompass stories from three American films: The Men ${ }^{11}$, Coming Home ${ }^{12}$, Waterdance. ${ }^{13}$ While each picture refers to a different historical period (respectively: World War 2, Vietnam War, early 1990s without the context of a military conflict), the protagonists' stories have many common points:

a) men are located in a medical centre temporarily, they are under treatment or rehabilitation;

b) despite varying experiences, views and social status, they create a support group that creates space for informal therapy;

c) while in each case, the dynamics of the adapting process towards the acquired disability may vary, they all experience it: from shock and denial, through anger and haggling, depression, and towards acceptance and constructive adaptation. ${ }^{14}$ Particularly, The Men and Waterdance protagonists are an example of the personification of particular phases of adaptation;

d) despite multidimensional adaptation contexts: permanence of the process, the need to redefine life aims, the lack of access to professional psychological support, the change of fulfilled social roles, in each of the aforementioned films, the particularly important theme is related to social relations ${ }^{15}$, especially the redefinition of the subjective model of man in relations with women (also in the context of sexual needs and prowess).

Apart from the above similarities, it is advisable to discuss the differences. The earlies film, The Men, begins with a scene where the physician explains paraplegia. While the character of the message is rather simple and direct (making it understandable), it essentially fulfils the educational role, even for the contemporary audience.

11 The Men, 1950, dir. F. Zinnemann, USA.

12 Coming home, 1978, dir. H. Ashby, USA.

13 Waterdance, 1992, dir. N. Jimenez, M. Steinberg, USA.

14 P. Wolski, Niepetnosprawność ruchowa. Między diagnoza a działaniem, Centrum Zasobów Ludzkich, Warszawa 2013, p. 24.

15 Ibidem, pp. 20-21. 
The film was made in a period, where many men would return from war damaged both psychologically and physically. Their state may be summarised by one of the protagonists: I was afraid (during the war - ed.) that I was dying. Now I am afraid that I will live. The anxiety against the unknown, new life was an experience of both veterans and their families, which was answered by the aforementioned film. Another difference is related to the context of the description of relations with women, which, in the 1950 film was mostly related to the role of the head of the family, a husband and Provider, rather than sexual partner. Moreover, contrary to later films, the hospital is not a transitional place for all men; some of the protagonists are willingly deciding remain there, performing autostigma $^{16}$ (related with the foreseen social exclusion - regardless of the actual circumstances). The main area of masculinity in The Men is the ability to fulfil the role of the Provider, and rehabilitation is mostly physical.

In subsequent films: Coming Home (1978) and Waterdance (1992), highlights are made regarding social, sexual rehabilitation and psychotherapy. The aim of remaining in the medical centre is to prepare the patients to integrate with the society, and not to create space that would divide both worlds - "normal" people and people with disabilities. Particularly, Coming Home, is an example of a critical voice against systemic solutions containing taboos (sexual rehabilitation, psychological disorders and patient suicides). In the film, acquired disability was also presented as a destructive experiences (the cause of suicide), but also creative - triggering new planes of activity (anti-war social activity). In both films, the essential aspect of the reconstruction of identity is the relation with the female partner, also in the sexual aspect. In this context, it is worth highlighting the differences between the male protagonists that present high

${ }^{16}$ M. Parchomiuk, Stygmatyzacja osób z niepetnosprawnością i choroba - mechanizmy działania i konsekwencje, [in:] Stereotypy niepetnosprawności. Między wykluczeniem a integracja, (eds.) M. Chodkowska, S. Byra, Z. Kazanowski, D. Osik-Chudowolska, M. Parchomiuk, B. Szabała, Wydawnictwo Uniwersytetu Marii Curie-Skłodowskiej, Lublin 2010, p. 84. 
sexual competency (Coming Home) and frustration related with the failed attempts of adapting sexual practices to lower prowess (Waterdance).

\section{Sexuality of persons with physical disabilities}

Another plane of scholarly analysis was the sexuality of persons with physical disability, which is decreasingly treated as a film taboo. Male and female sexuality regarding persons with physical disabilities is no longer within the area of suggestion or discussion, but is presented in the form of erotic scenes. Cultural presentations contained in drama, melodrama or slice of life films, take up a mature discussion regarding the needs and sexual capabilities of individuals with disabilities. Such films are as follows: The Theory of Flight ${ }^{17}$, Born on the Fourth of July 18 , Tiptoes ${ }^{19}$, Waterdance and The Sessions. ${ }^{20}$ Film presentations are dedicated to four groups of difficulties within the sexual plane:

a) anatomical, related to structure disorders (or functions) of sexual organs and/or the disorders among the entire organism;

b) physiological, resulting from causes that determine disability. It is the largest group of difficulties resulted with acquired physical disability, e.g. damage of the spinal cord;

c) psychological resulting from particular (sexual) experiences of an individual; expectations regarding the partner and building the intimate relation;

d) social and cultural related to the female and male models dominating in a given culture. The aforementioned difficulties are related the the feeling of lack of appeal, caused by the inability of meeting the heightened standards of beauty, as well as, social stereotypes that also result from such labels. ${ }^{21}$

17 The Theory of Flight, 1998, dir. P. Greengrass, Great Britain.

18 Born on the Fourth of July, 1989, dir. O. Stone, USA.

19 Tiptoes, 2003, dir. M. Bright, USA/France.

20 The Sessions, 2012, dir. B. Lewin, USA.

${ }^{21}$ K. Lutkiewicz, Seksualność osób z niepetnosprawnością ruchowa na podstawie wybranych uszkodzeń narządów ruchu, [in:] Niepetnosprawność ruchowa w ujęciu biopsy- 
As previously mentioned, regarding the forced asexuality of the heroine of You're not you, and it is an example of a stereotype, according to which the experience of disability impedes all planes of the individual's functioning, abolishing sexual needs as well. Declarations regarding the aforementioned needs meet with curiosity, shame or are being underestimated by the surrounding environment. It is a double standard example, according to which, needs are considered normal in the case of healthy individuals, and are considered improper, or unsubstantiated in declarations of persons with disabilities. ${ }^{22}$ Jane, the protagonist of The Theory of Flight is tackling such reactions, when she, as a paralysed person, wishes to experience sexual intercourse before death. Additionally, Mark from The Sessions, is pursuing sexual needs which he discovers as an adult man. Pursuing experiences in the case of protagonists is related to both informal and professional relations. Jane regrets that she did not initiate intercourse during the initial disease phase, and intends to substitute sex with the partner with masturbation and pornography. Experiencing a gradual loss of ability, the woman has an ambivalent attitude towards own body (me and my body separated) considering herself as an unappealing person (in a notice she writes: despicable cripple, young woman looking for sex). On the other hand, she is not interested in a partner with a disability. Despite the loss of ability, her erotic fantasies remain unchanged, while she realises, that having sex with her is a despicable activity. While Jane, attempts to perceive intercourse on a task basis, she is not able to make use of professional sexual services. Finally, she fulfils her dream with a man that is close to her.

In The Theory of Flight, the protagonist attempts to use the service of a prostitute, while Mark participates in the title Sessions with a professional sexual therapist. The area of the man's competency is his intellect - he is a poet, a writer, journalist, who is trapped in a disabled body (the statement has a figurative meaning - Mark is

chicznospołecznym. Wyzwania diagnozy, rehabilitacji $i$ terapii, (eds.) M. Bidzan, Ł.Bieleninik, A. Szulman-Wardal, Harmonia Universalis, Gdańsk 2015, pp. 209-210. 22 A. Ostrowska, Seksualność..., op.cit., p. 14. 
sustained by an artificial lung). The protagonist discovers his sexual needs only at 38 years of age, when he surprisingly reads a press article of other individuals with disabilities. Mark's "discovery" is an example of the lack of sexual education, the absence of which in the life of the majority of persons with disabilities results from stereotypical belief (fear) before unleashing the "improper" needs, and, in consequence, treating them as everlasting children. ${ }^{23}$ The primary aim of sexual therapy, in which the protagonist participates, is the cognition and acceptance of the body. A body which, in the case of persons with disabilities, is a source of oppression, and a symbol of boundaries. Mark is not displaying defiance against nudity in a medical context, as his body is subject to operations, however, he is unable to confront his (masculine) nudity with female nudity - he does not know his body as a source of pleasure. First experiences cause him to feel cleansed and victorious. During therapy, Mark has difficulty in maintaining professional relation, and his therapist - Cheryl - maintains keeping the boundaries. Her aim is to prepare the man to understand own preferences and sexual needs, to establish behaviour models and techniques considering his physical abilities, and to prepare him for intercourse with other women. Cheryl's therapy plan is an example of complex sexual rehabilitation, including educational and psychotherapeutic methods (learning own body and erogenous areas), counselling and psychotherapy within the cognitive and behavioural trend (working out the feeling of competence and acceptance of own body, as well as, its limitations), and training methods (masturbation training and practising as well as adaptation of sexual positions). ${ }^{24}$

However, not always do the sexual experience of individuals with disabilities prove to be satisfactory, and the means of adaptation, to be productive. An example of such narrative is Ronnie (Born

${ }^{23}$ W. Pilecka, Wychowanie seksualne w systemowej rehabilitacji dziecka niepetnosprawnego, [in:] Człowiek niepetnosprawny, rodzina i praca, (eds.) B. Aouil, M. Kościelska, Wydawnictwo Akademii Bydgoskiej, Bydgoszcz 2004, p. 112.

24 K. Lutkiewicz, Seksualność..., op.cit., pp. 234-235. 
on the Fourth of July), who, due to wounds suffered from the war, suffers from paraplegia. The man thinks, that in result of the wounds, he was paralysed nad castrated. Realising the role of the Protector, Ronnie lost the ability to find sexual satisfaction, and establish a family. Failed attempts at adaptation cause the man to be focused on his genitalia and sexual capabilities, however, simultaneously, it is an area of negation and frustration. Difficulties experienced by Ronnie strengthen the lack of support byt the religious family, for which sexuality is taboo, and rejection by his female partner (typical American beauty). Sexual practices of veterans, presented in the film, are related to using the services of ethnic prostitutes, giving the men any feeling of control (here: financial) during the intercourse.

\section{Film images of persons with physical disabilities in the early-exploitation phase}

The following three scholarly areas were sketched out on the basis of media changes of representations of individuals with physical disabilities, of chronological and qualitative aspect. The earliest type of images in the early-exploitation ${ }^{25}$ is taken from the freak-show tradition, and circus attractions that arouse tabloid interest: panoptica, travelling circuses, or sideshows, where people become living exhibits. Such attractions are available for but a brief period of time - their purpose is to bring joy, curiosity, scare the audience, and through the oddity of "human showpieces" and their "miserable fate" solidify the audience in their feeling of being normal ("my life is not that bad at all"). The reaction towards oddity is determined by social and cultural factors, varying regarding the historical period, but constituting an area of many interpretations: from aesthetic

${ }^{25}$ H. Żuraw, Cyrk Barnuma. Medialne wizerunki osób niepetnosprawnych i chorych, [in:] W kręgu niepetnosprawności: teoretyczne i praktyczne aspekty poszukiwań w pedagogice specjalnej, (eds.) L. Konopska, T. Żółkowska, Print Group Daniel Krzyżanowski, Szczecin 2009, p. 355. 
curiosity, a prodigy or a jest of nature, to the biological error (related to the lack or overabundance of tissue), or the punishment for sins. ${ }^{26}$ According to Hanna Żuraw: "visible dysfunctions also arouse curiosity. There, occurs the urge to gaze, while not gazing is the norm - to release the tension resulting from the dissonance, the individual intends to avoid contact with the stigmatised. Persons that are different yield attention - people are eager to gaze upon them and find interest in them". ${ }^{27}$ Oddity arouses ambivalent reactions that come from admiration and interest to fear and repulsion, from laughter to aggression, from compassion to contempt; it is a space for katharsis.

Freak show tradition, due to the characteristic above, seems as ideal inspiration for entertainment films. The examples of such pictures are Freaks ${ }^{28}$ and The Elephant Man ${ }^{29}$, the setting of which refers directly to the tradition of panoptica. In both films, physical oddity builds an atmosphere of horror and fantasy: before the Elephant Man appears on the scene, the tension related to his "monstrosity" is building the reactions of other characters in combination with medical descriptions. Due to the visible otherness, the title protagonist is always situated "between" the worlds - despite leaving the travelling panopticum, he still remains isolated within the psychiatric ward, under the care of a physician. The actions of the physician - caretaker, while motivated by the intent to help, inscribe in the segregation-care attitude ${ }^{30}$, according to which the specialist institution is the best form of support for persons with disabilities. While John Merrick's (the Elephant Man) living conditions improve significantly and he is treated subjectively, he still remains a form of

26 Z. Mikołejko, Dziwolagi ryciny. Świat monstrualny w dawnym drzeworycie niemieckim, „Kultura popularna” 2012, no 1, pp. 37-42.

${ }^{27} \mathrm{H}$. Żuraw, Udziat osób niepetnosprawnych w życiu społecznym, Wydawnictwo Akademickie "Żak”, Warszawa 2008, p. 47.

${ }^{28}$ Freaks, 1932, dir. T. Browning, USA.

29 The Elephant Man, 1980, dir. D. Lynch, USA/Great Britain.

30 A. Twardowski, Sytuacja rodzin dzieci niepetnosprawnych, [in:] Dziecko niepetnosprawne w rodzinie, (ed.) I.Obuchowska, Ed. III, Wydawnictwo Szkolne i Pedagogiczne, Warszawa 1999, p. 34. 
a showpiece, and his visits among the elite are nothing more than a more sophisticated form of a freak show.

Therefore, circus is the perfect space for oddity - it never remains in a given place for a longer period of time, it is always in the outskirts (remaining beyond a given society metaphorically and physically), its creators promise fantastic, incredible and thrilling show. Circus attractions give the audience the possibility to "gaze upon" oddity - without shame or a prick of conscience. Due to the above, the circus becomes a home, workplace, as well as, the "natural" space for the title Freaks. The film introduction warns the audience from contacting their oddity, and the entire title and the description language are straightforwardly negative. Notions that appear in the movie are as follows: living and breathing monstrosities, unusual and unwanted, eternal children, little men. The camera work and long shots allow to examine the oddity of the film characters thoroughly, where many persons with disabilities (actors) appeared, making the film a cinematographic freak show.

In both films, heroes with disabilities are transcending the boundary between "normality" and oddity. The relationship of a man of low posture (Hans) with an attractive woman (Cleopatra) is not accepted, raises curiosity and suspicion, both within the community of persons with disabilities, as well as, other circus workers. Already during the marriage of the aforementioned pair, the wife is humiliating the husband, refuses the opportunity to join the group of "the different" and is shocked by the fact that she is the one that must be accepted by persons with disabilities (and not vice versa). While the title, seemingly, refers to disability, the title freak is the mutilated Cleopatra - her oddity becomes the punishment for the sins, and a representation of her horrific nature. Watched within the historical context, the film gains a normative character, as the persons with disabilities presented within it are active, independent, and create a supportive community. In some scenes we may see examples of adapting to limitations, e.g. when a woman is eating dinner using feet, and man without limbs is lighting a cigarette.

In The Elephant Man film, the main protagonist experienced objectification, the example of which was his nickname recalling his 
status of a man-animal hybrid. It is noteworthy, that when he is pulled out of the cage, he discards his nickname and uses his real name anew. As John Merrick, the protagonist experiences the process of subjectification, where from a "monstrum" he becomes a patient, a man tormented by a disease; from the social margin, he is put under the Queen's patronage; he ceases vegetation and survival and can develop artistically and intellectually. In the process of pursuing own identity, John was no longer a scared being in a cage, but had become a human conscious of his own identity. On the other hand, this transformation had been accomplished due to the support of the physician, and the change of environment, and John himself to always be dependent on others. In the final scene, the man commits suicide - he suffocates, sleeping on his back. His death is another evidence for being unable to achieve normality (even in such a natural activity as sleep), but also an expression of satisfaction related to achieving "normality" that was within his grasp. John dies without regrets, saying: I am happy, my life is accomplished, because I know that I am loved.

The early-exploitation narrative is not only related to films within the historical context, but also within the fantasy-oriented one. As mentioned, in Freaks, a significant portion of the cast was made of persons with disabilities, and the Elephant Man is inspired by actual events. The motives from both films, within a surreal form, are combined by the Penguin from Batman Returns. ${ }^{31}$ Penguin is the missing ling between man and bird, and his repulsive apparition is a reflection of his unjust character. Penguins headquarters are beyond the are of the "ordinary world" - in the sewers, and its layout and the look of his minions refer to circus aesthetics, only highlighting their status as freaks. This villain is a personification of pretty good/different - evil dychotomy - which is often the basis of prejudice against persons with disabilities. ${ }^{32}$ The fall of the Penguin who

31 Batman Returns, 1992, dir. T. Burton, USA/Great Britaina.

32 K. Walęcka-Matyja, Psychologiczne $i$ społeczno-kulturowe determinanty postaw wobec osób niepetnosprawnych $i$ ich rodzin, [in:] Doświadczanie choroby $i$ niepetnosprawności, (ed.) E. Zasępa, Wydawnictwo Akademii Pedagogiki Specjalnej, Warszawa 2013, p. 29. 
cannot and does not want to be "normal" inscribes within the stereotype of a person with a disability as own sole and greatest enemy. ${ }^{33}$ Batman Returns is a fantasy flick, however the use of the image with a person with a disability as an outsider is often possible to relate to drama films set in the current reality. The example of such film is The Station Agent ${ }^{34}$, whose title protagonist is a person of low posture. While Finn is an introvert dreaming of a calm life, his arrival to a small town turns out to be a local sensation. According to him: It is really funny, how people see and treat me differently. Because in reality I am an uncomplicated and boring geek. The statement of the protagonist indicates a tendency to portray persons with disabilities via their exceptional, unnatural, extreme features, with the simultaneous omission of their normality. ${ }^{35}$

\section{Film images of persons with physical disabilities in the super-cripple phase}

The belief regarding the uniqueness of persons with disabilities lies as the basis of the subsequent phase of imagery presentation: super-cripples. ${ }^{36}$ It seems, that such imagery overcomes the monopoly of negative images, presenting people with disabilities as competent, more able than healthy persons, as well as, people of success. However, the presentations of super-cripples, while overcoming one stereotype, create another related to compensation. ${ }^{37}$ According to the stereotype, the deficit in one area is "compensated" by an exceptional talent, almost unnatural competencies in

33 C. Barnes, Disabling imagery and the media, Ryburn Publishing, Halifax 1992, pp. 14-15.

34 The Station Agent, 2003, reż. T. McCarthy, USA.

35 H. Żuraw, Udziat..., op.cit., p. 50.

36 C. Barnes, Disabling..., op.cit., pp. 7-14.

37 E. Nieduziak, Osoba niepetnosprawna w filmie i telewizji, [in:] Audiowizualność. Cyberprzestrzeń. Hipertekstualność. Ponowoczesne konteksty edukacji, (eds.) L. Jakubowska-Malicka, A. Kobylarek, M. Pryszmont-Ciesielska, Oficyna Wydawnicza ATUT, Warszawa 2009, p. 106. 
a different area. The attitude does not necessarily serve the community of persons with disabilities, however it constitutes the basis of moral order, "causing, that it is expected to compensate the events perceived as harmful. One of the forms of making amends for the loss of sight, is to bestow exceptional skills and virtues upon the blind. The belief regarding the world being just, therefore, the universality of an occurrence of a specific cause-effect relation, may not only yield compensation-oriented beliefs but also prejudice. ${ }^{38}$ Moreover, the compensation stereotype serves a motivational function for healthy persons, according to the belief that if a person with a disability may achieve success, that I surely can as well!

Film narrations of super-cripples draw from biographies of artists (My left foot $\left.{ }^{39}\right)$, sportsmen (De toutes nos forces ${ }^{40}$ ) or scientists (The Theory of Everything41). Christy Brown (My left foot) grew up in a working-class, numerous family. His father and brothers worked physically, however, he became a valued writer and poet. Brown was self-taught, for a long period of time, even the professionals would associate his physical disability (cerebral palsy) with intellectual disability. ${ }^{42}$ Despite the lack of systemic support and knowledge regarding disability, the family accepted Christy, and his mother was his first, informal therapist. The first patron of Brown's talent was his therapist, who promoted his artistic work. The film raises an interesting theme of the evaluation of the artist's work within the context of his disability, which is expressed by the words of Brown's exhibition curator: Many think that Christy is a great cripple painter. I think that it is an insult to him. (...) He is simply a great painter. Period. Like every painter, he struggled with his body, forcing it to obedience. Look around, and You will see forces that shaped him. His mother.

${ }^{38}$ M.J. Lerner, following: K. Błeszyńska, Niepetnosprawność a struktura identyfikacji społecznych, Wydawnictwo Akademickie "Żak", Warszawa 2001, p. 196.

${ }^{39}$ My left Foot: The Story of Christy Brown, 1989, dir. J. Sheridan, Ireland/Great Britain.

40 De toutes nos forces, 2015, dir. N.T avernier, France/Belgium.

41 The Theory of Everything, 2014, dir. J. Marsh, Great Britain.

${ }^{42}$ H. Zuraw, Udziat..., op.cit., p. 47. 
His father. His brothers and sisters. Another biography where success is related to an area independent of physical disability is The Theory of Everything, a biography of Stephen Hawking. Apart from the scientific success, the film describes the less known history of his private life. His wife, the agent of success, who supported the scientist in scholarly development, along with the advancing disease, would assume more responsibilities related to managing the family, and taking care of the husband. Gradually, Hawking, from a husband would turn to a patient. The film features the theme of the sexual competency of the man, and how he played the role of the father. When, during the phase when Hawking was at an advanced state of disease, he became a father, his family and relatives would accept this information with distrust, suspecting the man of impotence in regard to his disease (the asexuality stereotype), and his his wife of unfaithfulness. The history of the scientist is one of the few examples of success, both within the professional and personal areas.

The last of the films is De toutes nos forces, which describes the story of a gradual build of the relation between the father (Paul) and his disabled son (Julien) when preparing for sports competition. The disappointment related to the son's birth, caused the father to distance himself from the family, while all family responsibilities related to son's upbringing and therapy would fall on the mother, who represents the overprotective attitude. ${ }^{43}$ The aim of undertaking the sports challenge by the teenager with cerebral palsy is not only to overcome the physical limitations, but to build relations with the absent father. The film describes the area of accomplishments of persons with physical disabilities, which is present within the social awareness, in relation to the successes of paralympic sportsmen. According to A. Ostrowska, it results from the fact, that sports achievements are associated with a "field indicating fame, social acceptance and prestige, as well as, self-accomplishment achievements. The difference in the number of indications for sportsmen in

${ }^{43}$ M. Kościelska, Oblicza upośledzenia, Wyd. Naukowe PWN, Warszawa 1995, pp. 66-67. 
comparison to the success of others is enormous. Therefore, it is worth realising, that their successes are a resultant of individual features of persons, as well as, conditions that exist in their world, which is open to such success, or even supports it" ${ }^{44}$ Julien's history is a great example - his success is made possible due to his father's ability, and long years of complex therapy.

A breakthrough presentation within the context of the supercripple narrative is the Best Years of Our Lives film ${ }^{45}$, featuring an actor with a physical disability, Harold Russel. His career was determined by the propaganda character of the American cinema following World War 2. Russel would play the roles of veterans, trying do adapt to the post-war reality. The protagonist, Homer, is struggling with the challenges of adapting to disability in the social sphere (relation with the family and local society), psychological (the reconstruction of own identity), and emotional (the reconstruction of relations with his own fiancee). Despite the acceptance of his relatives, Homer rejects their attempts to aid and support, which is an example of the projection mechanism (ascribing particular motives and intentions to other people). ${ }^{46} \mathrm{His}$ negative reaction is related to the belief regarding the hidden motives behind supportive actions (placed in compassion, pity and attempts to objectify, and make subordinate). Therefore, why does this presentation inscribe within the super-cripple narrative? It is determined by the adaptation of the protagonist to the acquired physical disability - the loss of both hands. Homer is very able in using the prosthetics-hooks, and in particular scenes, one may notice his competencies and independence. Social reactions to his disability vary - from compassion (not to say pity), to admiration over his skills. The man does not hesitate to present his competencies, he stalls comments or responds to them in jokes - importantly, his reactions are much more constructive in the public sphere than in the private.

44 A. Ostrowska, Niepetnosprawni w społeczeństwie 1993-2013, Wydawnictwo IFiS PAN, Warszawa 2015, p. 234.

45 The Best Years of Our Lives, 1946, dir. W. Wyler, USA.

46 P. Majewicz, Obraz samego siebie a zachowanie młodzieży niepetnosprawnej ruchowo, Wydawnictwo Naukowe Akademii Pedagogicznej, Kraków 2002, p. 105. 
An important voice summarising the first two type of images, both stereotypical (while in different contexts), are words quoted by Gill Brearley: "a teenager with cerebral palsy said to me once I cannot decide, who I want to be - A GMC or Super-cripple. When asked for explanation, she said: I can be only one or the other, is it not? People expect me to be a Goddamn Miserable Cripple, begging and being patted on the head, or a Super-cripple that can take Mount Everest on a wheelchair, or pilot the Concorde plane without hands. Her friend referred sceptically to the statement: It does not matter what You choose, as long as You smile, she said. Joy must be visible on Your face - that is what the adults expect from You". ${ }^{4}$

\section{Film images of persons with physical disability in the normalisation phase}

Disability and normality are categories that are often considered separately. Semantics of the word dis-ability is based on negation and rejecting ability (normality). Therefore, according to P. Stanisławski "(...) persons with disabilities are mostly presented as triumphant over their own tragedy, or demolished by this tragedy. Sources that show them as ordinary people, just like the others, are few. The society perpetuates the image of disabled living «in a different world». If they are different and exceptional, they should be talked about in a special way". ${ }^{48}$ Imagery from the previously described phases: early-exploitation and super-humans are drawing from this belief about the amazing nature and Otherness in reference to negative and positive stereotypes. Such presentation are of so total nature (and the Otherness features so dominant) that in the presentations of persons with disabilities that can be included in the early-exploitation and super-humans phases, there is often a lack of space to inscribe new non-stereotypical and non-sensational meanings. Despite the mod-

${ }^{47}$ G. Brearley, Psychoterapia dzieci niepetnosprawnych ruchowo, trans. M. DońskaOlszko, Wydawnictwo Szkolne i Pedagogiczne, Warszawa 1999, pp. 13-14.

48 P. Stanisławski, Bohaterowie tylko jednego tematu, e-document: http://www. niepelnosprawni.pl/ledge/x/20977 [20.06.2020]. 
ern, multimedia form and tabloid content, contemporary presentations express the dualism of reaction to oddity, related to fascination or fear, that had already been observed during antiquity. 49

While the previous phases of image changes were of sensational and entertainment nature, the film attempts to normalise featured notorious didactic aspects, or are placed strongly within the idea of political correctness (visible particularly in American production). In such cases it is difficult to evaluate, whether film protagonists with disabilities acquire subjective features, or constitute theoretical constructions (created from a wishful perspective) describing not the aforementioned group but rather, being testament to the civilised nature of a given society.

The process of normalisation of film images of persons with disabilities remains in strict relation with social transformations and civilisation development. In Poland, particularly following the state transformation during the turn of the 1980s and the 1990s, and joining the European Union, the idea of integration has been becoming more popular, not only due to international legal regulations, but also funds dedicated both for the support of persons with disabilities and their families, but also to introducing changes in the awareness of the general public (social campaigns) and removing barriers in the public space. Gradually, also in the popular culture, particularly in television, more and more protagonists with disabilities would appear. The phenomenon was described byt W. Otto as "initiating" humanity. 50 According to the author ${ }^{51}$ film presentations of persons with disabilities during the normalisation period are constituted by:

a) referring to the spheres of private life: both emotional experiences and interpersonal relations, as well as, hobbies, professional and personal activity, and dreams,

b) presentation of daily practices,

${ }^{49}$ H. Żuraw, Cyrk Barnuma..., dz.cyt., p. 353.

${ }^{50} \mathrm{~W}$. Otto, Obrazy niepetnosprawności w polskim filmie, Wydawnictwo Naukowe UAM, Poznań 2012, p. 126.

51 Ibidem, pp. 125-139. 
c) presenting of individuals with disabilities without commenting on their state (e.g. the cause of disability) or the need to rationalise their appearance on screen,

d) grasping disability as one of many features that characterise the individual,

e) reference to general human experiences and emotions, common to all persons with disabilities, as well as, able individuals, e.g. love, fear of loneliness. ${ }^{52}$

Considerations related to normalisation images must begin with a reference to careers of actors with physical disabilities. While actors of low posture were often labelled for fantasy and science-fiction cinema, the career of Peter Dinklage is an example of overcoming this stereotype. While the actor appears in fantasy pictures, not all his roles are related to disability. In X-Men: Days of Future Past ${ }^{53}$ and Knights of Badassdom ${ }^{54}$, despite fantasy (science-fiction) plot, the disability is a transparent category. An example of an actor's different career pursuit that is deprived of references to physical disability is the work of Jamel Debbouze. This French actor (with one hand paralysed) appeared in films such as Le fabuleux destin d'Amélie Poutain ${ }^{55}$, Astérix \& Obélix: Mission Cléopâtre ${ }^{56}$, Hors- la-loi ${ }^{57}$, Sur la piste du Marsupilami58, Pourquoi j'ai (pas) mange mon pere. ${ }^{59}$ Despite the dominance of the comedic repertoire, the physical disability of the actor was never an object of ridicule; moreover, even in the animated movie, the character voiced over by Debbouze has one hand crippled.

52 Introduction to the description of normalisation presentations is a fragment of the unpublished dissertation of the author: Edukacyjne $i$ socjalizacyjne aspekty kultury popularnej. Obraz osoby z niepetnosprawnościa ruchowa w wybranych utworach sztuki filmowej.

53 X-Men. Days of Future Past, 2014, dir. B. Singer, USA/Great Britain.

54 Knights of Badassdom, 2013, dir. J. Lynch, USA.

55 Le fabuleux destin d'Amélie Poulain, 2001, dir. J.-P. Jeunet, France/Germany.

56 Astérix E Obélix: Mission Cléopâtre, 2002, dir. A. Chabat, France/Germany.

57 Hors- la-loi, 2010, dir. R. Bouchareb, France/Belgium/Tunis/Algiers/Italy.

58 Sur la piste du Marsupilami, 2012, dir. A. Chabat, France/Belgium.

59 Pourquoi j'ai (pas) mange mon pere, 2015, dir. J. Debbouze, Belgium/China/France/Italy. 
In terms of films, where healthy actors play as persons with physical disabilities, the example of normalisation images is $\mathrm{W}$ przypadku obrazów, w których zdrowi aktorzy wcielają się w postacie osób z niepełnosprawnościami ruchowymi, przykładem wizerunków normalizacyjnych jest Inside I'm Dancing. 60 The film tells a story of two young men (Michael and Rory), who, despite physical disabilities (Duschenne's muscular distrophy and cerebral palsy) attempt to live independently. Especially for Michale, who spent the entire life in a specialised care facility, the experiences outside the institution are breakthrough. Stay at the facility, which constituted the only "home", was an expression of a segregation attitude of his father - Michael was to receive professional care and therapy, but also his contacts with the family were limited: "the practical realisation of segregation concepts not only protected persons with disabilities from the difficulties of living in an open society, but also "protected» the society from living with persons with disabilities" ${ }^{61}$ Despite being an adult (birth certificate wise) Michael is a "grown child". The Inside I'm Dancing film presents the path of man becoming independent, as well as, the process of sped up maturing. Despite regular references to disabilities of the protagonists, the flow of the plot and the multidimensional nature of the characters, make the main thing of the film to be the pursuit of independence, and self-determination to a possible degree.

\section{Summary}

Analysing the presented study results, one may notice the existence of two discourses in film representations of persons with physical disabilities - dominant and alternative. Firstly, in the analysed films, the experience of disability becomes negative and filled with stereotypes. Against the aforementioned, the alternative discourse is related to normalisation images, bereft of tabloid vignette of sensation or oddity. Moreover, the dominant discourse is still the appre-

\footnotetext{
${ }^{60}$ Inside I'm Dancing, 2004, dir. D. O'Donell, France/Ireland/Great Britain.

${ }^{61}$ A. Twardowski A., Sytuacja..., op.cit., p. 36.
} 
hension of physical disability as a label, a total feature in building a character. (Physical) disability is an unseen category, lacking comment in the film narrative, it inscribes in the alternative discourse. Moreover, persons with disabilities are not individual protagonists, presented within the background of healthy individuals. Therefore, the film characters with disabilities pare placed within one presentation strategy, and they vary little. Numerous characters with disabilities in feature films are still an example of the alternative discourse, often placed within a specialist institution (in this view, expressing the isolation attitude). Furthermore, the experience of disability is most often described from a masculine perspective. As mentioned, the feminine perspective of disability is much less presented in films.

Despite the dominance of stereotypical and negative images, presenting disability as a label, it is advisable to observe representations that create the alternative discourse. The normalisation trend particularly includes images, where the (physical) disability changes from the title (un)seen difference into an unseen category. In such presentations, there is no need to "rationalise" the appearance of characters with disabilities on screen, and their otherness is no longer a total category. Images inscribing in the normalisation discourse are postulated by persons with disabilities. When asked about the representation of the groups in media, they state that they are mostly a "show off", and the person with a disability is primarily "shown as a human, that does something remarkable despite the disability, as well as, an incapable person in need of others". Persons with disabilities consider the most beneficial representations to be linked with categories such as "normality", appeal, usefulness. ${ }^{62}$ While the process is a long-stretch and affected by varying factors, as audience we are witnesses to the gradual appearance of such, normalisation oriented imagery in the media.

62 I. Fornalik, Wizerunki osób niepetnosprawnych w mediach - media w percepcji niepetnosprawnych, [in:] Świat peten znaczeń: kultura i niepetnosprawność, (eds.) J. Baran, S. Olszewski, Oficyna Wydawnicza „Impuls”, Kraków 2006, pp. 511-513. 


\section{References}

Barnes C., Disabling imagery and the media, Ryburn Publishing, Halifax 1992.

Barnes C., Niepetnosprawność, trans. P. Morawski, Wydawnictwo Sic!, Warszawa 2008.

Błeszyńska K., Niepetnosprawność a struktura identyfikacji społecznych, Wydawnictwo Akademickie "Żak”, Warszawa 2001.

Brearley G., Psychoterapia dzieci niepetnosprawnych ruchowo, trans. M. Dońska-Olszko, Wydawnictwo Szkolne i Pedagogiczne, Warszawa 1999.

Dąsal M., Męskie inicjacje - rytuaty w życiu wspótczesnego mężczyzny, [in:] Męskość w kulturze wspótczesnej, (eds.) A. Radomski, B. Truchlińska, Wydawnictwo UMCS, Lublin 2008.

Fornalik I., Wizerunki osób niepetnosprawnych w mediach - media w percepcji niepetnosprawnych, [in:] Świat pełen znaczeń: kultura i niepetnosprawność, (eds.) J. Baran, S. Olszewski, Oficyna Wydawnicza „Impuls”, Kraków 2006.

Kościelska M., Oblicza upośledzenia, Wyd. Naukowe PWN, Warszawa 1995.

Lutkiewicz K., Seksualność osób z niepetnosprawnościa ruchowa na podstawie wybranych uszkodzeń narządów ruchu, [in:] Niepetnosprawność ruchowa w ujęciu biopsychicznospołecznym. Wyzwania diagnozy, rehabilitacji $i$ terapii, (eds.) M. Bidzan, Ł. Bieleninik, A. Szulman-Wardal, Harmonia Universalis, Gdańsk 2015.

Majewicz P., Obraz samego siebie a zachowanie młodzieży niepetnosprawnej ruchowo, Wydawnictwo Naukowe Akademii Pedagogicznej, Kraków 2002.

Marszałek L., Niepetnosprawność - kobiecość - rodzina, Wydawnictwo Uniwersytetu Kardynała Stefana Wyszyńskiego, Warszawa 2006.

Melosik Z., Tożsamość, ciało i władza w kulturze instant, Oficyna Wydawnicza „Impuls", Kraków 2010.

Mikołejko Z., Dziwolagi ryciny. Świat monstrualny w dawnym drzeworycie niemieckim, „Kultura popularna” 2012, no. 1.

Nieduziak E., Osoba niepetnosprawna w filmie i telewizji, [in:] Audiowizualność. Cyberprzestrzeń. Hipertekstualność. Ponowoczesne konteksty edukacji, (eds.) L. Jakubowska-Malicka, A. Kobylarek, Pryszmont-Ciesielska M., Oficyna Wydawnicza ATUT, Warszawa 2009.

Ostrowska A., Seksualność osób niepetnosprawnych, [in:] O seksualności osób niepetnosprawnych, (ed.) A. Ostrowska, Instytut Rozwoju Służb Społecznych, Warszawa 2007.

Ostrowska A., Niepetnosprawni w społeczeństwie 1993-2013, Wydawnictwo IFiS PAN, Warszawa 2015.

Otto W., Obrazy niepetnosprawności w polskim filmie, Wydawnictwo Naukowe UAM, Poznań 2012.

Parchomiuk M., Stygmatyzacja osób z niepetnosprawnością i choroba - mechanizmy dziatania i konsekwencje, [in:] Stereotypy niepetnosprawności. Między wykluczeniem a in- 
tegracja, (eds.) M. Chodkowska, S. Byra, Z. Kazanowski, D. Osik-Chudowolska, M. Parchomiuk, B. Szabała, Wydawnictwo Uniwersytetu Marii Curie-Skłodowskiej, Lublin 2010.

Pilecka W., Wychowanie seksualne w systemowej rehabilitacji dziecka niepetnosprawnego, [in:] Człowiek niepetnosprawny, rodzina i praca, (eds.) B. Aouil, M. Kościelska, Wydawnictwo Akademii Bydgoskiej, Bydgoszcz 2004.

Stanisławski P., Bohaterowie tylko jednego tematu, e-document: http://www.niepel nosprawni.pl/ledge/x/20977 [20.06.2020]

Twardowski A., Sytuacja rodzin dzieci niepetnosprawnych, [in:] Dziecko niepetnosprawne w rodzinie, (ed.) I. Obuchowska, Wyd. III, Wydawnictwo Szkolne i Pedagogiczne, Warszawa 1999.

Walęcka-Matyja K., Psychologiczne i społeczno-kulturowe determinanty postaw wobec osób niepetnosprawnych $i$ ich rodzin, [in:] Doświadczanie choroby i niepełnosprawności, (ed.) E. Zasępa, Wydawnictwo Akademii Pedagogiki Specjalnej, Warszawa 2013.

Wolski P., Niepetnosprawność ruchowa. Między diagnoza a działaniem, Centrum Zasobów Ludzkich, Warszawa 2013.

Żuraw H., Udział osób niepetnosprawnych w życiu społecznym, Wydawnictwo Akademickie "Żak”, Warszawa 2008.

Żuraw H., Cyrk Barnuma. Medialne wizerunki osób niepetnosprawnych i chorych, [in:] W kręgu niepełnosprawności - teoretyczne i praktyczne aspekty poszukiwań w pedagogice specjalnej, (ed.) L. Konopska, T. Żółkowska, Print Group Daniel Krzyżanowski, Szczecin 2009.

\section{Filmografia}

Le fabuleux destin d'Amélie Poulain, J.-P.Jeunet, France/Germany, 2001.

Astérix \& Obélix: Mission Cléopâtre, A. Chabat, France/Germany, 2002.

Pourquoi j'ai (pas) mange mon pere, J. Debbouze, Belgium/China/France/Italy, 2015.

The Elephant Man, D. Lynch, USA/Great Britain, 1980.

The Station Agent, T. McCarthy, USA, 2003.

Freaks, Tod Browning, USA 1932.

Inside I'm Dancing, Damien O'Donnell, France, Ireland, Great Britain, 2004.

Tiptoes, M. Bright, USA/France, 2003.

My left Foot: The Story of Christy Brown, Jim Sheridan, Ireland, Great Britain, 1989.

Sur la piste du Marsupilami, A. Chabat, France/Belgium, 2012.

The Best Years of Our Lives, William Wyler, USA 1946.

You're not you, George C. Wolfe, USA 2004.

An Affair to Remember, Leo McCarey, USA 1957.

The Men, Fred Zinnemann, USA 1950. 
Hors- la-loi, R. Bouchareb, France/Belgium/Tunis/Algiers/Italy, 2010.

Batman Returns, T. Burton, USA/Great Britain, 1992.

Coming home, Hal Ashby, USA 1978.

Knights of Badassdom, Joe Lynch, USA 2013.

The Sessions, Ben Lewin, USA 2012.

The Theory of Flight, Paul Greengrass, Great Britain, 1998.

Waterdance, N. Jimenez, M. Steinberg, USA, 1992.

The Theory of Everything, James Marsh, Great Britain, 2014.

Born on the Fourth of July, Olivier Stone, USA, 1989.

La grande bellezza, Paolo Sorrentino, Italy, France, 2013.

X-Men. Days of Future Past, B. Singer, USA/Great Britain, 2014.

De toutes nos forces, Nils Tavernier, France/Belgium, 2015. 